\title{
Interactive comment on "Development of the drop Freezing Ice Nuclei Counter (FINC), intercomparison of droplet freezing techniques, and use of soluble lignin as an atmospheric ice nucleation standard" by Anna J. Miller et al.
}

Anna J. Miller et al.

nadine.borduas@usys.ethz.ch

Received and published: 5 February 2021

The comment was uploaded in the form of a supplement:

https://amt.copernicus.org/preprints/amt-2020-414/amt-2020-414-AC1-

supplement.pdf

Interactive comment on Atmos. Meas. Tech. Discuss., doi:10.5194/amt-2020-414, 2020. 